\section{Preservation of scientific and cultural heritage in Balkan countries}

Cultural heritage in Balkan countries

Yaşar Tonta

Department of Information Management, Hacettepe University, Ankara, Turkey

\begin{abstract}
Purpose - The peoples living in the Balkan Peninsula over centuries have created a very rich cultural heritage and the constant political upheavals in the region have affected the development and preservation of their cultures. This paper aims to review the internet infrastructure and networked readiness levels of the Balkan countries, which are conducive to scientific co-operation and preservation of digitised cultural heritage. It also explores the destructive effects of wars on the cultural riches of the region.

Design/methodology/approach - The internet facilities and the scientific production of the Balkan countries were identified using published sources and Thomson's Web of Science database. A game-theoretic approach was used to expound the consequences of wars and the adverse effects of the nation-building process on cultural heritage artefacts.

Findings - Balkan countries lack sound internet infrastructures, hindering their contributions to the world of science and stifling scientific co-operation among themselves in terms of joint papers. The co-ordinated efforts have yet to exist to streamline the digital preservation of the unique cultural heritage of the Balkan countries.

Originality/value - This paper discusses the impact of the nation-building process on cultural and scientific heritage artefacts using the concepts of the "game theory". It reinforces the fact that destroying the cultural heritage artefacts during wars is not a "zero-sum game" in which the dominant culture wins and the "other" culture loses. It is not even a "lose-lose game" in which both parties lose. Rather, humanity loses part of its whole cultural heritage forever.
\end{abstract}

Keywords Digital storage, Heritage, Culture, Internet, Game theory

Paper type Research paper

\section{Introduction}

The word "balkan" in Turkish means a range of wooded mountains. It was first used for the Balkan Mountains in Bulgaria. Later in the nineteenth century, the word was used to describe the Balkan Peninsula as a geographical region, which is defined as an "area of southeastern Europe surrounded by water on three sides: the Adriatic Sea to the west, the Mediterranean Sea (including the Ionian and Aegean seas) to the south and the Black Sea to the east" (http://en.wikipedia.org/wiki/Balkan_peninsula). The region was ruled by the Ottoman Empire for a long time and harsh independence wars

The author would like to thank colleague and friend Professor Mícheál Mac an Airchinnigh who introduced him to the concept of the "digital re-discovery of culture".

This paper is based on the invited keynote paper presented at the International Symposium on Information/Documentation Management and Cooperation among the Libraries in the Balkan Countries that was held in Edirne, Turkey, from 5-7 June 2008.
Received 12 March 2009

Revised 1 July 2009

Accepted 10 July 2009 
PROG

43,4

420 took place during the last quarter of the nineteenth and the beginning of the twentieth centuries. Great human tragedies were experienced by the peoples speaking various languages, having various religious and ethnic backgrounds who then populated the region. The political unrest in the Balkans continued throughout the twentieth century, especially during the First and Second World Wars and the years after the Cold War ended. The process of building "nation states" in the region still continues.

The word balkan took on, albeit unjustly, a pejorative meaning due to wars, turbulence and disarray experienced in certain parts of the Balkans for the last two centuries and new derivations of the word, with negative connotations (e.g. "balkanisation"), came into existence. This may well be the reason why Slovenia refused to be identified as a "Balkan country" after Yugoslavia was dissolved in 1992. Countries in the Balkan Peninsula seem to prefer nowadays being identified as "Southeast European" or, in the case of Slovenia and Croatia, "Central European" countries (http://en.wikipedia.org/wiki/Balkans). Some sources continue to identify the whole Balkans as a "dangerous place to live in" (aneki.com, 2008).

Yugoslavia was known as the Socialist Federal Republic of Yugoslavia prior to 1992. Then Croatia, Slovenia, Macedonia and Bosnia \& Herzegovina declared independence and the Federal Republic of Yugoslavia, comprising Serbia and Montenegro, was set up. The Federal Republic was reconstituted in 2003 as the State Union of Serbia and Montenegro. In 2006 a referendum was held and the Montenegrins chose to become an independent state. Therefore Serbia and Montenegro, the remnants of the former Yugoslavia, became separate independent states. Lastly, Kosovo declared her independence from Serbia in February 2008. The independent states in the region include Albania, Bosnia \& Herzegovina, Bulgaria, Croatia, Greece, Kosovo, Macedonia, Montenegro, Romania, Serbia, Slovenia, and Turkey, although Romania, Slovenia and Turkey are "located mostly outside the peninsula" (http://en.wikipedia.org/wiki/ Balkan_peninsula) (see Figure 1).

Some 75 million people live in the Balkan Peninsula. If the people living in the Anatolian part of Turkey, which does not geographically belong to the Balkan Peninsula, are added, the total population of the Balkan countries rises to 142 million (2009 data), which makes up 17.7 per cent of the European population.

\section{Internet infrastructure and scientific co-operation among Balkan countries}

The quality of life in the region is much lower than that of the average of the European Union (EU) countries. As shown in Table I, some 36.8 per cent of the population have access to the internet in Balkan countries as compared to 61.4 per cent in EU countries overall, that is 50 million people with internet access in the region (26.5 million of which are from Turkey).

Figures and percentages for Balkan countries were prepared by the author based on data available at the Internet World Statistics web site (www.internetworldstats.com/ europa2.htm) and specific figures and percentages for each Balkan country are shown in Table II.

Turkey ranks sixth among European countries in terms of the number of total internet users. The Balkan countries are connected to GÉANT2, the high-speed European Research and Education Network, as shown in Figure 2 with modest bandwidth capacities (except Croatia, Slovenia and, to some extent, Greece). 


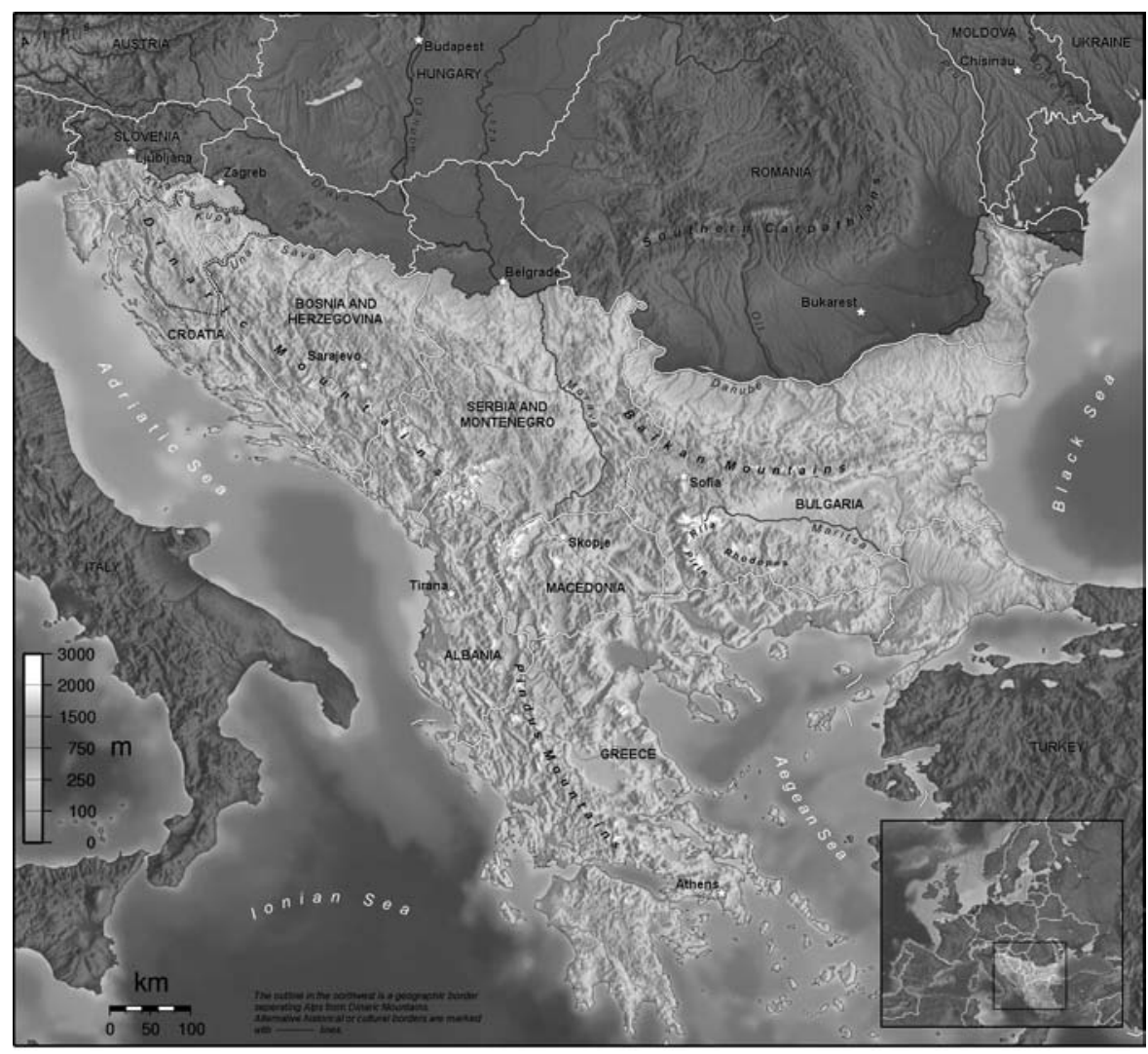

Source: http://en.wikipedia.org/wiki/Balkans

\section{Cultural heritage in Balkan countries}

421

Figure 1. The Balkan Peninsula

The Balkan countries are ranked low in the Networked Readiness Index of 2007-2008 (2008), which compares 127 countries, with the top-ranking countries being Denmark, Sweden, Switzerland and the USA. Slovenia ranks 30th, Croatia 49th, Turkey 55th, Greece 56th, Romania 61st, Bulgaria 68th, Macedonia 83rd, Bosnia \& Herzegovina 95th, and Albania 108th.

Contributions of the Balkan countries to the world of science are limited. Table III gives the total number of publications listed in Thomson ISI Web of Knowledge citation indexes in April 2008 (http://apps.isiknowledge.com/) for the Balkan countries. It can be seen that Turkey and Greece each have more than 100,000 publications to their credit; they rank 21st and 22nd in the world list. Data about Yugoslavia covers the geographic area and the political entities that existed under the name of "Yugoslavia" during different time periods in the last century and beyond. Addresses that belonged to the Republic of Macedonia and those that belonged to Greece's Macedonia Region were identified and the number of publications were calculated accordingly. Other Balkan countries have fewer publications (Bulgaria: 53,795; Romania: 53,269; and "Yugoslavia": 49,018). The newly established states (after Yugoslavia's split) published even fewer 
PROG

43,4

422

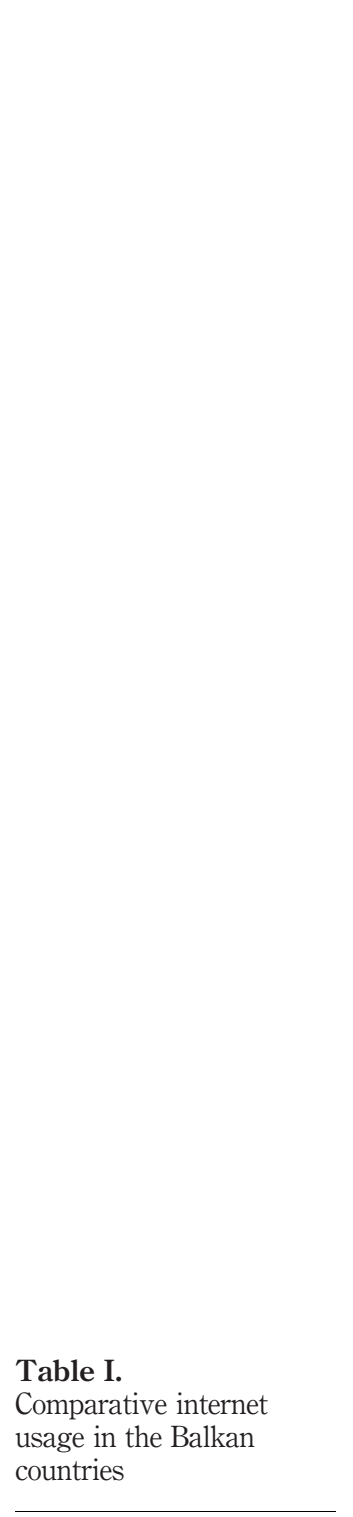

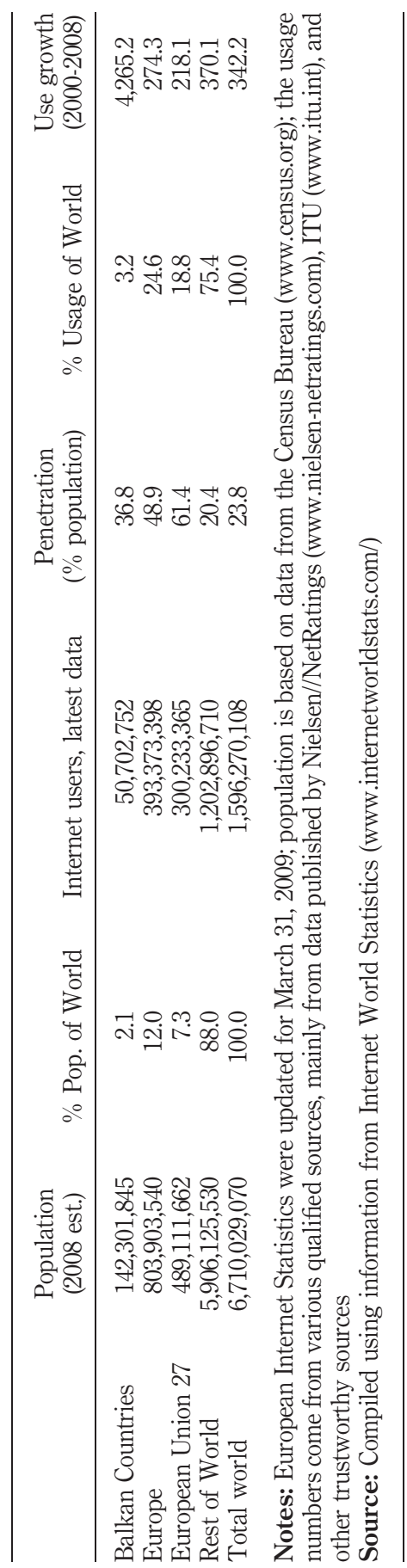




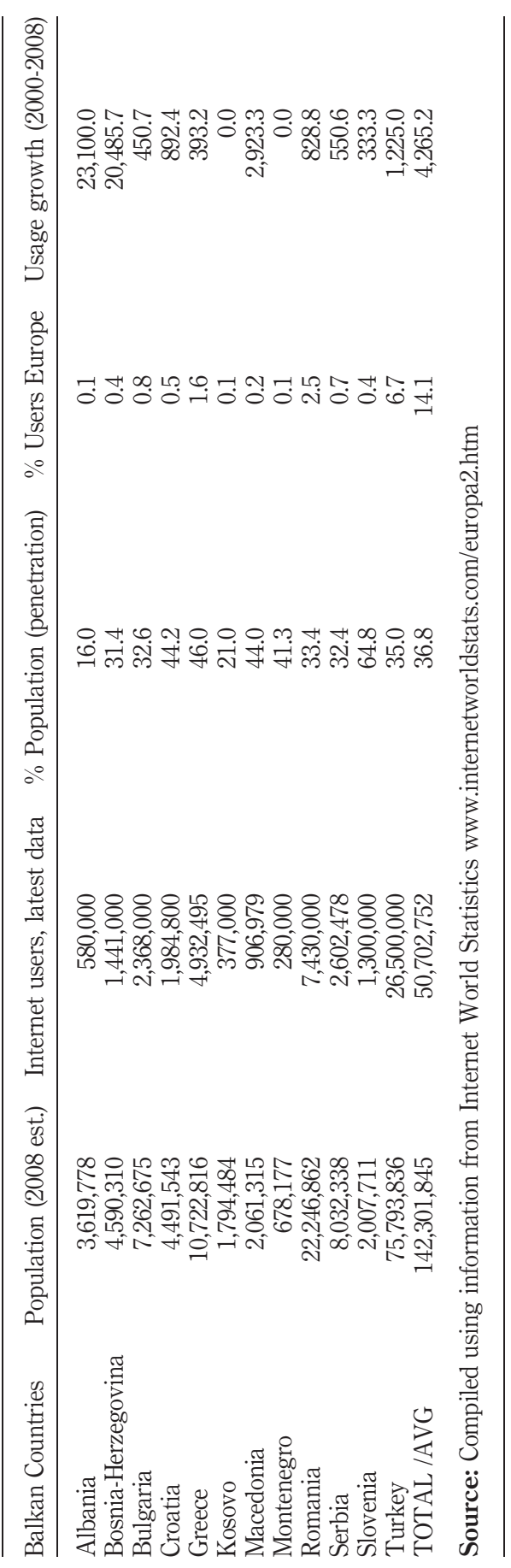

Cultural heritage in Balkan countries

423

Table II. Internet usage in the Balkan countries 


\section{PROG}

43,4

\section{4}

\section{Figure 2.}

Schematic map of the high-speed European Research and Education Network, topology (February 2009)

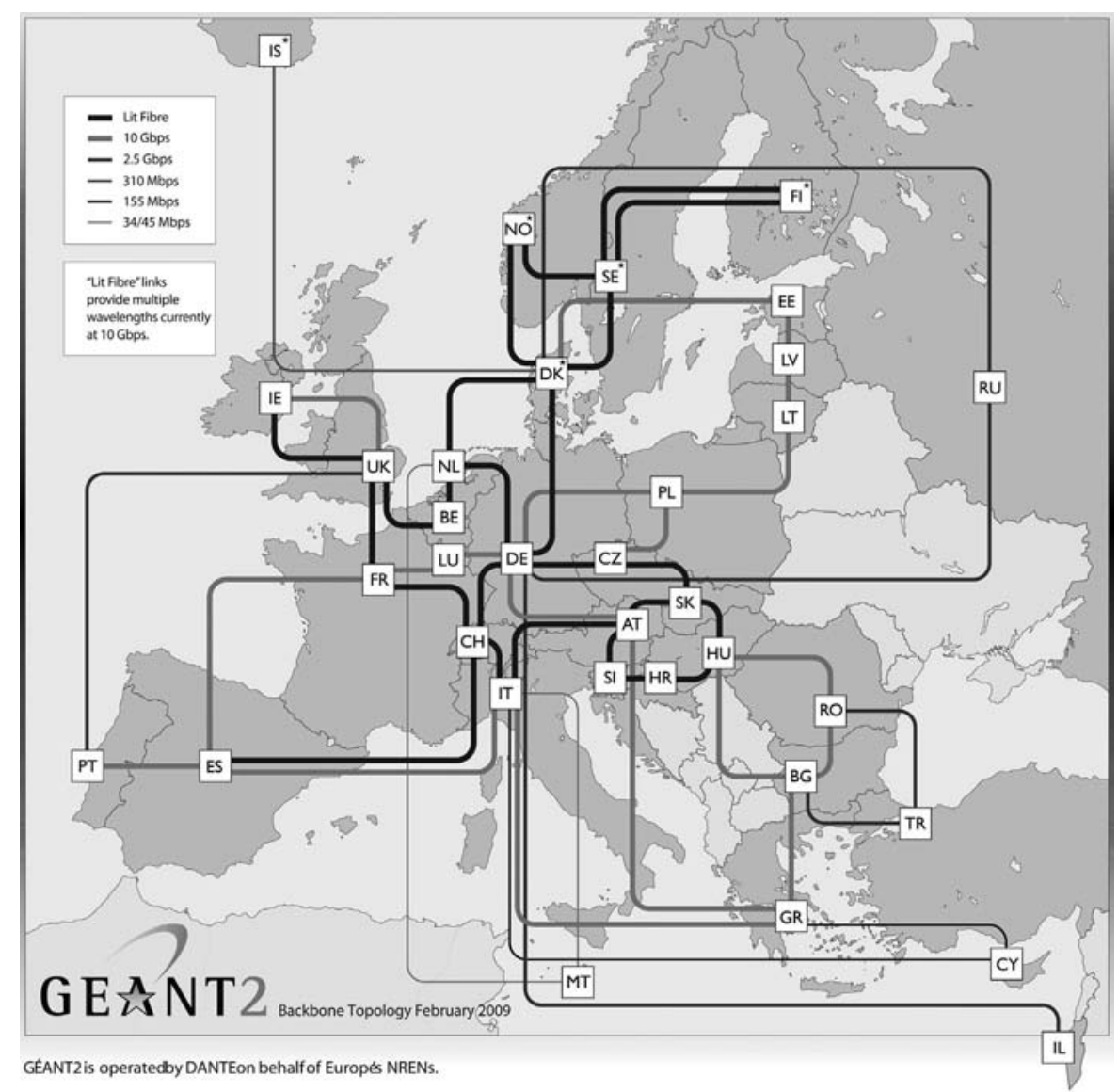

Source: http://www.geant2.net/server/show/nav.00d007009

papers (Slovenia: 25,033; Croatia: 24,116; Serbia: 9,910; Macedonia: 2,272; and Bosnia \& Herzegovina: 1,124). Albania, Montenegro and Kosovo follow these countries with 780, 317 and 51 papers, respectively.

Scientific co-operation among Balkan countries is also limited. Very few joint papers have been published by scholars living in the Balkan countries. For instance, Turkish scholars published 428 joint papers with their colleagues in Greece, 267 with Bulgaria and 214 with Romania (much less than 0.5 per cnet of all papers with Turkish addresses). Similarly, Greek scholars published 671 and 482 joint papers with their Bulgarian and Romanian colleagues, respectively. Bulgarian and Romanian scientists produced 526 scientific papers together. Scientific co-operation among other Balkan countries is even scarcer. (These figures were obtained by carrying out an advanced search for addresses on Web of Knowledge: e.g. "ad = bulgaria and romania" to identify papers jointly published by the Bulgarian and Romanian scholars.) 


\begin{tabular}{lrr}
\hline Country & No. of publications & $\begin{array}{r}\text { Cultural heritage } \\
\text { in Balkan } \\
\text { Countries }\end{array}$ \\
Turkey & $\sim 100,000$ & \\
Greece & 100,000 & \\
Bulgaria & 53,795 & $\mathbf{4 2 5}$ \\
Romania & 53,269 & \\
"Yugoslavia" & 49,018 & 25,033 \\
Slovenia & 24,116 & \\
Croatia & 9,910 & 2,272 \\
Serbia & 1,124 & Table III. \\
Macedonia & 780 & \\
Bosnia-Herzegovina & 317 & \\
Albania & 51 & Number of publications \\
Montenegro & & in the Balkan countries \\
Kosovo & & \\
Source: Thomson ISI citation indexes & & \\
\hline
\end{tabular}

\section{Cultural heritage of the Balkan countries}

Although the scientific co-operation is limited among Balkan countries, these countries share a very rich cultural heritage. Monuments, intellectual and artistic works making up the cultural heritage have been affected by the turbulent times experienced in the Balkans for the last two centuries. Some creative works of the Balkan communities were unfortunately lost forever due to wars and negligence, thereby decreasing the common cultural riches of the region (Riedlmayer, 1995a, 1995b). The destructive effects of wars on cultural riches are still being experienced in geographical regions not too far from the Balkans. Professor Mac an Airchinnigh's (2004) paper on digital preservation starts with a moving account of the destruction of the collections of the National Library of Iraq in March 2003.

One of the causes of this is the nation-building process itself. For each nation identifies its citizens, not on the basis of civic duties and rights, but usually on the basis of language, religion, ethnic background or a combination thereof. In the end, the cultural heritage of the people who lived in the same country earlier, but were identified as the "other" in the nation-building process, tends to get neglected by the citizens of the new "nation state". As a matter of fact, this is not a good experience for the dominant culture of the new nation state either, as the works of the common cultural heritage gets affected negatively (Mac an Airchinnigh et al., 2006). A recent example of this was experienced when the National and University Library of Bosnia \& Herzegovina was firebombed and destroyed during the night of August 25/26, 1992, as shown in Figure 3.

More than 1.5 million books, including about 4,000 precious rare books and manuscripts, were destroyed during the incident. About 10 per cent of the Library's collection was saved by Sarajevo citizens. The Library is still closed to the public. Zgonjanin (2005, pp. 136-137) describes the loss of the artefacts of all cultures involved more eloquently:

It is ironic that the National and University Library of Sarajevo, identified as an enemy target allegedly by Bosnian Serb forces, contained the history and cultural heritage of all the peoples who lived in Bosnia and Herzegovina: Muslims, Serbs, Croats, Jews, and others. 


\section{PROG}

43,4

426

Figure 3.

The National and University Library of Bosnia and Herzegovina in Sarajevo in 1992

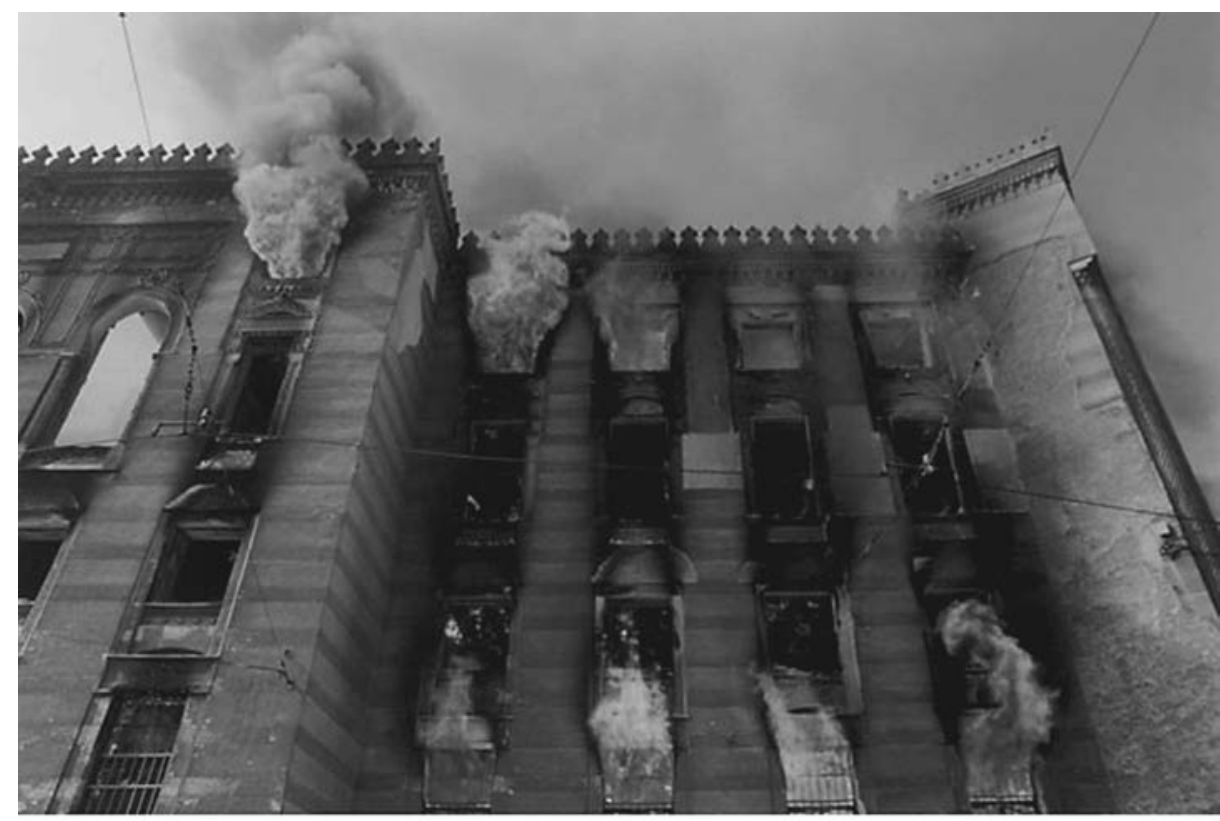

Source: http://www.theeuropeanlibrary.org/exhibition/buildings/images/pictures/bos_115.jpg

Destroying one's own cultural heritage because it is part of the cultural pluralism that existed on that territory for centuries seemed to be cultural suicide and at the same time exposed the intricate nature of culture. This was an exemplary case showing that culture is not an isolated entity and that by destroying other people's culture one destroys one's own at the same time, for all cultures are interwoven and depend on each other.

Perhaps "the Balkan Alzheimer's disease" prevents us from remembering the contributions of the "other" to our very own culture! In a novel, A Partisan's Daughter, the author Louis de Bernières characterises a Serbian woman (Roza) who hates Turks, Croats, Albanians and almost everyone and jokingly depicts her as a person having "the Balkan Alzheimer's disease" that would make one "forget everything but a grudge" (De Bernières, 2008, p. 51).

As the Sarajevo example shows, destroying cultural heritage is not a "zero-sum game" in which the dominant culture wins and the culture of the "other" loses. This cannot even strictly be described as a game in which both parties lose. It is worse than that because a similar experience is usually repeated in the country where the culture of the "other" is the dominant one. Consequently, not only do the cultural riches of both countries get lost, but also humanity is deprived of part of its whole cultural heritage.

The development of information and communication technologies (ICTs) globalised human knowledge and it is now possible to make the whole human memory accessible to every individual and to reproduce it exactly in different places (Dyson, 1997, pp. 10-11). Yet, once lost it is almost impossible to reproduce or recreate cultural heritage. Cultural riches are not limited to intellectual and artistic works only: performances and other creative products of human beings (such as intangible cultural 
activities) are also a part of this cultural heritage. Cultural objects get forgotten as time passes, unless they are recorded. Although the recorded ones have longer lives, they too eventually decay (Lyman and Kahle, 1998).

Fortunately, the efforts to digitise the works of cultural heritage in order to preserve them in perpetuum have accelerated within the last decade. On August 24 2006, the European Commission (EC) adopted a "Recommendation on the Digitisation and Online Accessibility of Cultural Material and Digital Preservation" urging members to set up large-scale digitisation facilities for cultural materials, to provide online access to Europe's cultural heritage through the European Digital Library, and to develop national strategies and plans for the long-term preservation of, and access to, digital material (Tonta, 2008). The "digital culture" thus created "transcends the national and social boundaries with which culture is usually associated" (Mac an Airchinnigh, 2008).

On the other hand, the 2005 Convention on the Protection and Promotion of the Diversity of Cultural Expressions of UNESCO, presupposes "recognition of equal dignity of and respect for all cultures, including the cultures of persons belonging to minorities and indigenous peoples" (Mac an Airchinnigh et al., 2006). "Along with the 1972 Convention concerning the Protection of the World Cultural and Natural Heritage and the 2003 Convention for the Safeguarding of the Intangible Cultural Heritage, this Convention is one of the three pillars of the preservation and promotion of creative diversity" (Unesco, 2005). The digitisation of the works of the cultural heritage of minorities makes them the property of all humanity and facilitates co-operation on an international level for long-term preservation of the cultural heritage.

As libraries, archives and museums all over the world strive to make their contents accessible to everyone through the World Wide Web, they are becoming virtual destinations (Tonta, 2008). The development of standards and interoperable systems makes it possible to perform simultaneous "federated searches" on thousands of "open archives". As such applications become more widespread, the number of stakeholders responsible for the protection and promotion of scientific and cultural heritage increases. Contributions to science, culture and art by different countries and societies become more visible and the scientific and cultural heritage of the humanity thus becomes more universal.

The "digital culture" and "digital science" provide a sound base to initiate and streamline co-operation on regional (e.g., among Balkan countries) as well as international levels. The European Commission's i2010: Digital Libraries Initiative aims to provide access to "Europe's cultural and scientific heritage at a click of a mouse" (European Commission, 2005). Several digitisation programmes have been introduced to facilitate access to a richer European scientific and cultural heritage through the web. Examples include:

- DIGICULT (Digital Heritage and Cultural Content Programme of the European Commission).

- CALIMERA (Cultural Applications: Local Institutions Mediating Electronic Resources).

- COINE (Cultural Objects in Networked Environments).

- ERPANET (Electronic Resources Preservation and Access Network).

- NEDLIB (Networked European Digital Library).

\section{Cultural heritage in Balkan countries}

427 
PROG

43,4

428
As part of the i2010 policy, the EC funded the Europeana - Europe's digital library, museum and archive - under the eContentplus programme. The Europeana aims to provide online access to the digital content of European museums, libraries, archives and audio-visual collections and involves 90 representatives of European heritage and knowledge institutions including 20 national libraries. The Europeana web site was launched in November 2008 "giving users direct access to some 2 million digital objects, including film material, photos, paintings, sounds, maps, manuscripts, books, newspapers and archival papers" through a multilingual user interface (www. europeana.eu). The number of digital objects available through the Europeana portal will reach six million by the year 2010 .

However, the cultural heritage institutions of Balkan countries are under-represented in the Europeana Project with the inclusion only of The New Bulgarian University Library, Veria Central Public Library of Greece, University of Patras Library and Information Center of Greece, The National Library of Slovenia, and the Institute for Cultural Memory of Romania. Similarly, the European Library (www.theeuropeanlibrary.org) provides access to the contents of only four Balkan national libraries (Croatia, Greece, Serbia, and Slovenia).

\section{Conclusion}

Co-operation on both regional and international levels to set up "digital science" and "digital culture" repositories should not be seen as countries and institutions with relatively more resources and services "helping out" the less fortunate ones. Co-operative initiatives set up with this approach are usually doomed to failure. The word "co-operation" can be defined as two or more institutions, countries, etc. working together to provide more developed and varied services to their users and stakeholders. This definition presupposes that institutions or countries cannot usually provide such services satisfactorily if they act alone. Therefore, co-operation in a real sense requires, to some extent, "interdependence" between the interested parties such as libraries, archives, and museums of respective countries.

The regional and international co-operative programmes carried out to preserve and manage the scientific and cultural information sources in the Balkan countries should be increased. As successful digitisation, protection and management of information sources is closely related with the availability of networking facilities, the internet infrastructures of the Balkan countries needed to support the "digital science" and "digital culture" should be studied to identify applications and services that can be streamlined through co-operative endeavours.

\section{References}

aneki.com (2008), Dangerous Countries to Live In, available at: www.aneki.com/dangerous.html (accessed 13 June 2009).

De Bernières, L. (2008), A Partisan's Daughter, Harvill Secker, London.

Dyson, G. (1997), Darwin Among the Machines, Penguin Books, London.

European Commission (2005), "Staff Working Document. Annex to the Communication from the Commission ‘2010: Digital Libraries' COM(2005) 465”, available at: http://eur-lex.europa. eu/LexUriServ/LexUriServ.do?uri=CELEX:52005SC1194:EN:NOT (accessed 13 June 2009). 
GÉANT2 (2008), "Lighting the pathway for European research and education", available at: www.geant2.net/upload/pdf/GN2_Topology_Feb_09.pdf (accessed on 13 June 2009).

Lyman, P. and Kahle, B. (1998), "Archiving digital cultural artifacts: organizing an agenda for action”, D-Lib Magazine, Vol. 4 No. 6, available at: www.dlib.org/dlib/july98/07lyman.html (accessed 13 June 2009).

Mac an Airchinnigh, M. (2004), "Practical sense of philosophizing: why preserve anything at all, even digitally?", Review of the National Center for Digitization, No. 4, pp. 111-34, available at: www.ncd.matf.bg.ac.yu/casopis/04/d014/download.pdf (accessed 13 June 2009).

Mac an Airchinnigh, M. (2008), "The digital culture", in Ender, B. and Ekinci, Y. (Eds), Information/Documentation Management and Cooperation among the Libraries in the Balkan Countries Symposium Papers, 5-7 June 2008, Edirne/Turkey, (Publications of the Rectorate of Trakya University No. 87), Trakya University, Edirne, pp. 75-83.

Mac an Airchinnigh, M., Sotirova, K. and Tonta, Y. (2006), "Digital re-discovery of culture game of inquiry \& the physicality of soul", Review of the National Center for Digitization, No. 9, pp. 19-37, available at: www.ncd.matf.bg.ac.yu/casopis/09/NCD09019.pdf (accessed 13 June 2009).

Networked Readiness Index (2008), “2007-2008 Rankings”, available at: www.weforum.org/pdf/ gitr/2008/Rankings.pdf (accessed 13 June 2009).

Riedlmayer, A. (1995a), "Maziyi silmek: Bosna-Hersek’teki kütüphanelerin ve arşivlerin tahribi, Türk Kütüphaneciliği”, available at: www.kutuphaneci.org.tr/web/node.php?action= $6 \&$ type $=6 \&$ target $=$ contentShow\&id=994\&node_id=128 (accessed 13 June 2009), Vol. 9 No. 3, pp. 337-41.

Riedlmayer, A. (1995b), "Erasing the past: the destruction of libraries and archives in Bosnia-Herzegovina”, Middle East Studies Association Bulletin, Vol. 29, pp. 7-11.

Thomson Scientific, Inc. (2008), "ISI web of knowledge", available at: http://apps.isiknowledge. $\mathrm{com} /$ (accessed 13 June 2009).

Tonta, Y. (2008), "Libraries and museums in the flat world: are they becoming virtual destinations?”, Library Collections, Acquisitions, \& Technical Services, Vol. 32 No. 1, pp. 1-9.

Unesco (2005), "Convention on the Protection and Promotion of the Diversity of Cultural Expressions", available at: http://portal.unesco.org/culture/en/ev.php-URL_ID= 35405\&URL_DO=DO_TOPIC\&URL_SECTION=201.html (accessed 13 June 2009).

Zgonjanin, S. (2005), "The prosecution of war crimes for the destruction of libraries and archives during times of armed conflict", Libraries \& Culture, Vol. 40 No. 2, pp. 128-44.

\section{Further reading}

Bilar, E. and Ekinci, Y. (Eds) (2008), Information/Documentation Management and Cooperation among the Libraries in the Balkan Countries Symposium Papers, 5-7 June 2008, Edirne/Turkey, Publications of the Rectorate of Trakya University No. 87, Trakya University, Edirne, pp. 8-13.

Internet World Stats (2008), "Usage and population statistics", available at: www. internetworldstats.com (accessed on 13 June 2009).

\section{Corresponding author}

Yaşar Tonta can be contacted at: tonta@hacettepe.edu.tr

To purchase reprints of this article please e-mail: reprints@emeraldinsight.com

Or visit our web site for further details: www.emeraldinsight.com/reprints

\section{Cultural heritage in Balkan countries}

429 